\title{
Delegation Policy Implementation Model of Regent's Authority to District Head (Camat) on Local Autonomy in Nias Regency North Sumatera Province
}

\author{
Ayler Beniah Ndraha \\ Student at Doctoral Program IPDN Indonesia, \\ Civil Servant from Nias Regency (North Sumatera, Indonesia). \\ Email: aylerndraha@gmail.com. \\ Prof. Dr. Khasan Effendy, M.Pd \\ Student at Doctoral Program IPDN Indonesia, \\ Civil Servant from Nias Regency (North Sumatera, Indonesia). \\ Dr. Ella Wargadinata, M.A., M.Si \\ Student at Doctoral Program IPDN Indonesia, \\ Civil Servant from Nias Regency (North Sumatera, Indonesia). \\ Dr. Kusworo, M.Si \\ Student at Doctoral Program IPDN Indonesia, \\ Civil Servant from Nias Regency (North Sumatera, Indonesia).
}

Received: June 16, 2019 Accepted: July 12, 2019 Online published: July 28, 2019

doi:10.5296/jpag.v9i3.14936 URL: https://doi.org/10.5296/jpag.v9i3.14936 


\section{Abstract}

Recent policy has an orientation into national policy for find the pattern of regional development acceleration by minimalizing chance of budget leakiness that assumed to be unefficient, then lower governmental form learns to find a synergy to the upper governmental. While the upper government still on autonomy implementation until today rectified over and over again about authority in autonomy or institution aspect and controlling resources from regency to village. National Act Number 23 in 2014 about Regional Government only reaches the border of regional government affairs that also become a reference for regency to teach lower government, which is village. Besides, village and its governmental implementation has been guaranteed judicially through National Act Number 6 in 2014 about Village. Both national acts have consequences to guarantee realization of good governance of regencies/cities and/or villages so they can perform their autonomy to control and arrange each area of it. The data analyzed as qualitative phenomemologically.

Based on research results and discussion, we conclude that (1) Delegation policy implementation model of Regent's authority to head district at Nias Regency not fully has meaning that the head district acts the regional affairs. This assumed that the delegation of authority to head district from Nias' regent has not reached the truly authority that actually need to be handed over to head district for decide the fastest people's sake. (2) Some factors impede the delegation of regent authority to head district at Nias Regency which are: district's apparatus were classified less than good even form quantity and quality, the budget also classified as could not fulfilled people's demand about maximum services, and there were no sincerity from technical agency to hand over the job authority to head district, which is, in this case, impressed as a long and compicated process then affects the lateness of law production that became head district's standard to maximalize service to the people as a realization of authority devolution regent to head district at Nias Regency; (3) Created model in this research was an answer to implementation of authority delegation from regent to head district by looking people substances, regional headman and insitution aside.

Keywords: Implementation Policy Model, Authority Delegation, Organization Development, Regional Autonomy and Decentralization

\section{Introduction}

Since Law No. 5 of 1974 until the issuance of Law No. 23 year 2014 about local government has led to the dynamics of governance in Indonesia that is shifting more and more to suit the needs of Governance. LAW No. 23 of 2014 about local government which is are today is expected to be able to organize the area to organize autonomous government.

In order to implement regional autonomy needs synergity and cooperation of central Government with the region to perform or conduct the public duties of Government and the affairs of the Government authorized to the region with the principle Decentralization. Decentralization can be interpreted as the recognition or surrender of the authority of the higher general bodies to the lower general bodies to independently and based on the consideration of its own interests in making regulatory decisions and The governance and 
structure of the authority are included in the principles of Division of authority (Hoogerwerf, 1982:500).

Decentralization is a hope and challenge for the democratization process of Indonesia. In the past it tends to apparatus work only executes and organizes what is directed from the central government or the government on its upper level, very little that is an initiative of the local government, and if even there is still Waiting for clues from a higher level and also meaningful as a return on central government self-esteem. In addition, the decentralization policy for regional autonomy is essentially a correction to the failure of the system's centralization and unifomization governments that have been in effect.

The implementation of the principle of regional autonomy provides flexibility to govern and manage the region and the interests of its people in accordance with the legislation. The authority of the area increased many kinds and also its quality, which requires that the regional apparatus can take care of the authority to achieve the purpose of the regional autonomy, namely improving the welfare of the people, the more Prime service and Empowering communities.

One effort to achieve that is through the delegation of authority from the Regent/mayor to Camat to conduct part of government affairs and Development. Kecamatan or district is one of the regional devices that become a public service provider in the working area led by a public business to carry out the general tasks of government and regional autonomy in its work area and the implementation of government affairs Conducted by Camat by obtaining part of the authority of the regional head (Ndraha, 2000:85-90).

The delegation of authority from the regent to Camat is the demand of citizens to obtain easy service, cheap, fast and quality, as well as the mandate of the ACT No 23 years 2014 on local government, especially the article 221 paragraph (1) that the subdistrict or so-called by another name is part of the area of the Regency/city led by the district. The regulation was then derived in the form of government regulation No. 43 of 2014 which specifically regulates the duties and powers of the village, especially the construction and supervision of villages in the area of the subdistrict.

The subdistrict, led by a Camat, in the performance of its duties acquired a portion of the authority of the regent or mayor to handle some of the regional autonomy. The same mandate is also stated in government regulation No. 18 year 2016 on regional device organisation guidelines in section 50 paragraph 4 reads that "In addition to carrying out the duties as referred to in paragraph (3), the head performs the duties bestowed By the Regent/mayor to implement some government affairs which is the authority of the district/city."

As a manifestation of effective and efficient governance, Nias Regent has issued a policy in the form of regulation of Nias Regent No. 8 year 2014 about the authority of the regent to Camat. In the rule of the regent, there are several areas that are the authority of the regent which hereinafter bestowed on Camat. Delegated authority includes licensing services and non-licensing services. Authority of the Government according to the rules of the regent include licensing aspects, recommendations, coordination, coaching and supervision. 
Nias Regency is divided into 10 sub-districts consisting of Gido sub-district, Hiliduho subdistrict, Idano Gawo Sub-district, Botomuzoi subdistrict, Hiliserangkai subdistrict, Ma'u subdistrict, Somolo Molo subdistrict, Sogae'adu Sub-district, Ulugawo sub-district and subdistrict A. These sub-districts have different characteristics that most of these sub-districts are newly formed districts so that practical community service activities in this district are still lacking. Service is considered to be problematic one of them in licensing. This is because the region of Nias regency itself has different characteristics and connectivity between one region and another region is still not well connected. The local government of Nias Regency should increase and maintain the existing road network for the smooth accessibility to further promote economic growth in order to increase its kesejahteraanmasyarakatnya. But if there are too many road networks, it will also require considerable maintenance costs, while the local government is still constrained by the limitation of road handling funds. Therefore, it is necessary to plan the priorities of road network development and other supporting infrastructure to make the handling more effective and efficient.

Nias Regency to accelerate the regional independence through the implementation of governmental tasks and regional autonomy is often constrained by the geographical location of the district, most of the Nias Regency is set in the geographical region of the mountains. One of these factors led to a delay in development in all areas of the government in Nias Regency. Extensive Data on the region and population density of Nias Regency by subdistrict is presented in the following table 1.1:

Table 1.1 Total Area and Population Density of Nias Regency in 2018

\begin{tabular}{|c|c|c|c|c|}
\hline & $\begin{array}{c}\text { Kecamatan } \\
\text { District }\end{array}$ & $\begin{array}{c}\text { Luas }\left(\mathbf{k m}^{2}\right) \\
\text { Total Area }\left(\mathrm{km}^{2}\right)\end{array}$ & $\begin{array}{l}\text { Penduduk } \\
\text { Population }\end{array}$ & $\begin{array}{c}\text { Kepadatan } \\
\text { Penduduk } \\
\text { Population Density } \\
\end{array}$ \\
\hline 1 & Idanogawo & 231,61 & 26,826 & 115.82 \\
\hline 2 & Bawolato & 189,75 & 23,960 & 126.27 \\
\hline 3 & Ulugawo & 98,31 & 10,091 & 102.64 \\
\hline 4 & Gido & 105,68 & 21,235 & 200.94 \\
\hline 5 & Sogaeadu & 89,55 & 9,683 & 108.13 \\
\hline 6 & Ma'u & 69,85 & 6,420 & 91.91 \\
\hline 7 & Somolo-molo & 35,39 & 9,421 & 266.21 \\
\hline 8 & Hiliduho & 68,4 & 12,514 & 182.95 \\
\hline 9 & Hili Serangkai & 63,46 & 9,398 & 148.09 \\
\hline \multirow[t]{2}{*}{10} & Botomuzoi & 52,06 & 11,065 & 212.54 \\
\hline & NIAS & $1.004,06$ & 140,613 & 140.04 \\
\hline
\end{tabular}

Source: BPS Nias, 2018

Nias regency with an area of $1004.06 \mathrm{~km} 2$ is inhabited by 140,613 inhabitants, so the average population density of Nias is 140 people per $\mathrm{km} 2$. The most populated sub-district is Somolo-Molo sub-district, which is 266 people per km2, while the least is Mau subdistrict 91 orangper $\mathrm{km} 2$. The area with an unbalanced density is often an obstacle for Nias people to 
improve the quality and well-being of their lives.

In accordance with the above picture, temporary data shows that in the year 2016 through LKPJ AMJ Nias Regent Period 2011-2016 explained some results of the performance achievement of the local government of Nias regency that still need to be addressed including the provision of services Areas in this area throughout the sub-district in Nias Regency. The local government recognizes that there are weaknesses related to the slow handling of public problems in Kecamatan.

In relation to this, it takes a government unit that is located between the District government/city with the Government village/Kelurahan, called "Kecamatan" led by "Camat". This subdistrict is not merely a "working area", but is a "territory of government", has government authority (although in the administrative sense) in terms of building, supervising, facilitating and organizing maintenance Government policy, provincial government, district/municipality in the village/Kelurahan. Kecamatan also plays as an aikomunikator between the Regency/city government and the village, which is commonly referred to as "Verlengstuuk" or the extension of the Regency/city government. In carrying out this function, then most of the Regency/city authority, especially concerning the authority of the public administration and the direct service of the community bestowed to the district. Coordination of village/Kelurahan development planning is important to be played by the district, including harmonising between the needs of villages/Kelurahan with a Regency/city program (Rahmawan, 2016).

Based on the LKPJ resume of Nias Regency in 2010 until the year 2012 general problems of the village still dwell on public government activities that at the moment the condition of villages in Nias district are eager to be in the process of the situation Less conducive, which is backed by many of the things that the Nias Regency government sees is likely to cause a split in the middle of society. Such failure can be solved when the regent and mayor have a political desire to make the District a community service center. Therefore it is legitimate if the Regent/mayor then withdraw some of the authority that has been distributed to the head of regional service to be redistributed to Camat. It is an erroneous view when there is a head of service that feels its authority is taken by Camat, because that happens is the redistribution of authority done by the Regent/mayor (Rahmawan, 2016).

Nias District government expects the role of Camat to minimize the village that is not worth to be framed, but the will of the village community is hard to be dammed let alone is only facilitator in the middle of the village community. It is obvious that the villages of 126 villages in Nias Regency are divided into 146 as well as the proposed village until the year 2010 will greatly impact the size of the APBD of Nias Regency, while revenues received through the PAD are not Up to 30 billion per year until the year 2016 (last year) (LKPJAMJ of Nias Regent, 2011-2016).

Camat in the district leadership should be powerful and assertive and respond quickly to the public interest in its working area legally. Therefore, in carrying out the task of the authority that is increasingly dynamic every time and develops in the direction of regional development required leaders who are able to morally mobilize resources to implement government affairs 
in the working area. According to Northouse, leadership is the process by which an individual influences a group of individuals to achieve a common goal. Defining leadership as a process means it is not a trait or characteristic that is in the leader, it is the transactional event that occurs between the leader and the follower. This process implies that the leader affects and is influenced by his followers. This emphasizes that leadership is not linear, one-way, but rather an interactive event. Leadership has an influence, this relates to how leaders influence their followers. The cause of influence is sine qua nonwith leadership, without influence, no leadership (Mualiddin, 2013:1).

In fact Camat has not been able to apply good leadership as portrayed by Behn. Camat has not been able to move the subdistrict apparatus to carry out activities imposed by the District government so that the achievement of the program is not maximized. In addition, the cam has not been able to create a conducive work environment so that many employees can not cooperate with each other. The success of achieving the goals also depends on the individuals in the Working Group, especially in their leadership. The Working Group consists of a group of people with different abilities, talents, experiences and backgrounds gathered together to achieve one goal. Despite the differences between them, the common goal is a unified liaison as a working group (Marhalaung, 2014:33-40).

The above conditions, researchers are interested in conducting research with a focus on implementing a model implementation policy of Nias regent to the head of regional autonomy in Nias Regency.

\section{Literature Review}

\subsection{Public Policy}

Public policy is a binding decision for the crowd at a strategic or outline level made by a holder of a public authority. As public-binding decisions then public policy should be made by political authorities, those who accept the mandate of the public or the crowd, generally through a process of election to act on behalf of many people. Furthermore, public policy is implemented by the administration of the state that is run by government bureaucracy. The public policy as a decision is taken to act in order to provide service to the public according to the norms that are publicly available. The norms are concerned with the interaction of the rulers, the organizers of the state with the people and how should public policies be implemented. The Normatifnya measures are social justice, citizen participation and aspirations, environmental issues, service, administrative accountability and ethical analysis.

Policy is a written rule which is the formal decision of the organization, which is binding, governing conduct with the aim of creating new governance in the community. The policy will be the primary reference of members of the organization or community members in behavior. The policy is more adaptive and intepretatif, although the policy also regulates the "what can, and what should not be". Policies are also expected to be public but without eliminating specific local features. The policy should provide the opportunity to be interpreted according to specific conditions. 


\subsection{Implementation of Public Policy}

Grindle explained that public policy implementation includes a series of activities arising after the ratified State policy guidelines. Grindle states, implementation is a common process of administrative action that can be researched at a specific program level (Grindle, 1980:6).

The success of implementation according to Grindle is influenced by two large variables, the content of policy and the context-implementation environment (Grindle, 1980:18). Variables include: Where the interest of the target group or the target group is contained in the policy content, the type of benefits received by the target group, as well as the desired change of a policy, whether the location of a program has been Right, whether a policy has mentioned its implementation in detail, and whether a program is supported by adequate resources. Grindle added that the new implementation process will begin when the objectives and objectives are set, the activity program has been arranged and the funds are ready and have been channeled to reach the target (Grindle, 1980:7).

Based on the above factors, namely environmental conditions, relations between organizations, organizational resources for the implementation of programs, characteristics and capabilities of implementing agents is important in influencing a program implementation. These factors will result in the performance and impact of a program i.e. the extent to which a program can achieve a defined goal, knowing how to change administrative capabilities of local organizations, as well as various outputs and other results.

\subsection{Kecamatan, Authority of Camat, and Delegation of Authority to Camat}

In order to administer the local Government in accordance with the mandate of the Constitution 1945, regional governments governing and managing government affairs according to the principle of autonomy and assisted duty, are directed to accelerate the realization of Community welfare through improved service, empowerment and community participation, and increasing regional competitiveness by observing the principles of democracy, equitable, fairness, privilege, and peculiarities of an area in the system Unitary State of the Republic of Indonesia. Local government in law No. 23 Year 2014 concerning local government is the implementation of government affairs by local governments and DPRD according to the principle of autonomy and co-administration with the principle of autonomy widest in the system and The principles of the unitary Republic of Indonesia as referred to in the Constitution of the Republic of Indonesia year 1945. While the meaning of the local government is governor, regent, or mayor, and regional devices as an element of local governance.

In relation to regional autonomy, it is right to contain the sense of power to govern self regelen and self-management, while the obligation has two definitions, namely horizontal and vertical. The authority horizontally means power to administer the government as it should, and the authority vertically means the power to run the government in an orderly order of the state's government as a whole.

In the general provisions of Law No. 23 of 2014 concerning local government, especially in article 1 , which in particular explains the central government, hereinafter referred to as the 
Government is the President of the Republic of Indonesia Who holds the government authority of the Republic of Indonesia as intended in the law of the Republic of Indonesia year 1945. Local government in article 1digit (2) is the organizer of government affairs by the local government and DPRD according to the principle of autonomy and co-administration with the principle of autonomy widest in the system and principles of the unitary Republic of Indonesia As intended in the Constitution of the Republic of Indonesia Tahun1945 and (3) hinting that the local government is governor, Regent or mayor and regional device as an element of regional government organizers.

The subdistrict is the line office of the local government that is directly facing the community and has the task of building villages/villages. In carrying out the duties of local governance, the Adequationary device carries out governmental functions such as governance, development, community, including carrying out service duties and implementing Tasks delegated by the regent. Camat has a basic task of carrying out government authority bestowed by the regent. Camat in carrying out duties and obligations assisted by a district secretary, head of the section, head of sub-sections and staff.

The delegation of some authority of the Regent/mayor to Camat is not merely to give the legalization of authority to Camat, but rather directed to the efforts to improve the effectiveness and efficiency of services to the community and the use of funds and The public facilities effectively and efficiently. Delegation of authority should be able to encourage the creation of ease and speed of access for the community to obtain service, while opening the opportunity of community participation in the development of the subdistrict.

\subsection{Skeletal Thinking}

The current policy is still oriented towards the national policy to find an acceleration pattern for the regional development by minimizing the opportunity of the military leakage which is considered inefficient next form of government in the new lower level of learning Looking for a synergistic pattern with the upper level government still dwell on the affairs of regional autonomy that until now still in the improvement of both the authority in the autonomy and institutional aspects and management of sources Power of autonomy in the area to the village. Law Number 23 of 2014 still only reaches the boundaries of local government affairs at the district or city level, which is also a regional guideline for the development of the Government at the lower level of the village. Meanwhile, the village and governance in the village have secured the organizers juridically through LAW No. 6 year 2014. Both laws have consequences for ensuring the realization of the governance order of both the district/city and or village can organize its autonomic order to organize and manage each of its territories.

PP Number 19 year 2008 has explicitly set about it. As a regional device, the sub-district is gaining authority in terms of public service affairs. In addition, the subdistrict will also assume the implementation of general governmental tasks. Camat in carrying out its task is assisted by the Sub-district device and responsible to the regent or mayor through the district Secretary (SEKDA). This does not mean that the Camat is a direct subordinate to the district because it is structurally directly under the Regent or mayor. However, the responsibility of the Camat is administrative accountability (Hamudi, 2009). It is worth realizing that often the 
change in the form of local government legislation that has been so far changed is the dynamics due to the process of finding the right form and effectively consider the territory of the NKRI very diverse and Ability and readiness of different regional resources. The tide is the intensity of the government interests both central and regional are concentrated on how to conduct good governance and in accordance with the intent and purpose of autonomy that certainly emphasizes the integrity of the unity of the nation in the country RI.

The implications of the above phenomena can be seen from the coordination of local governments with village governments who have not been optimal. As an example of implementation of government programs in the village through the recognition of autonomy of villages allocated through village funds is often a matter of the output of the activities or programs of the village government has not synchronized with District or city governments, especially in road and bridge infrastructure, residential and residential areas. Not to mention with the delay of the village to improve the independent business program in the village that is less guided/noticed by the district/city government. The village has the legal force to publish village planning documents and also village law products in the form of village regulations, village head regulations and village head decisions. As mentioned above that the result of ACT No. 6 of 2014 about the village, the village has been of legal force as an autonomous territory of the Government, not administratively, because the village has had a village government agency namely village head and the BPD.

Very important sub-district functions are sometimes less concerned. Strengthening resources that are often asked by Camat to help technical tasks especially in the empowerment of village communities in the management of village funds from planning to accountability is often the complaint of Camat due to lack of The staff of the Office of the Camat to dribble and guide the village's devices. The current condition is very dilemma the village government Tatklala also has the authority to organize and manage its own household but Camat acts as a facilitator for empowering village community over its own village program. A series of national and regional programs also have the final target of the village, but to ensure the synergy of national programs, regions and villages required the right device as a controller to build and supervise directly in the field.

Thus, the function of the subdistrict is very strategic to provide guidance and direction to the village that is covered in its working area. Thus, arrangements for the implementation of Kecamatan both from the side of formation, position, duties and functions are legalistic governed by government regulations. Development of quality apparatus concerning development in terms of technical knowledge, theoretical, conceptual, moral, and responsibility in accordance with the needs of the work both with the educational and training, internship, and training for apparatus The professional in its duties (Sultan, 2007). In PP 19 years 2008 Camat has a task that almost overall represents the local government in the region, but because of Camat being put in front and facing directly with the community makes Camat a target complaint even In village community protests due to lack of attention from local governments. 


\section{Research Method}

\subsection{Research Design}

This research approach uses qualitative methods with a fermenological perspective. This qualitative study can be used to understand social interactions, for example with in-depth interviews so that the patterns will be found to be clear.

The statement means: "Qualitative research is aimed at achieving a deep understanding of a specific organization or event, rather than describing the surface of a large sample of a population. The research also aims to provide an explicit explanation of the broad structure, order and pattern found in a group of participants. Qualitative research is also called ethno-methodology or field research. The research also generates data on human groups in social settings. "

\subsection{Research Concept Framework}

In conducting a study it is necessary a framework of concepts that become the direction of the study. Public policy implementations can be seen from some perspectives or approaches. For the implementation of the policy, Grindle describes the model whose basic idea that once the policy is transformed, then the policy implementation is done. Grindle, an inspired research result of socio-political scientists in several cases of policy occurring in third world countries such as Asia, Africa and Latin America, looks more interested and focuses on conflicts in policy-making often occur (Grindle, 1986:34). Therefore, the questions that arise related to policy implementation revolve around decision-making conflicts; "Who gets what".

\subsection{Analyzers and Informant Units}

The analysis unit according to Hamidi (Hamidi, 2005:75-76) is a unit of study that could be individuals, groups, objects or a background of social events such as individual activities or groups as the subject of research. So to be able to find an analysis unit in this research, researchers will use the analysis unit of the informant to obtain the necessary information during the research process. Determination of informant in this study using purposive sampling technique (Cresswell, 2005:9). And the key informant (key informant) of the research is chosen based on the individual or group of people who have information, more directly involved, and who understand the problems that exist in the research in depth, but also Individuals or groups of people who have an educational background (background) or side experience in accordance with this research both from the experience and background of his education.

\subsection{Data Validity Analysis Techniques}

The validity test of data is a crucial factor in determining the validity of data in qualitative research. The validity test of the data has several criteria that Lincoln and Guba (1985) according to, namely: (1) credibility , (2) transferability, (3) dependability and (4) confirmability. 


\subsection{Data Collection Techniques}

The technique of data collection in this research is a deep interview to the participants (key informant) and documentation. Documentation is to collect data by way of documentation, researchers browse various documents, such as books, magazines, newspapers, meeting notes, rules, and other secondary sources of information. The documents are commonly used in qualitative research that can become a government document research instrument that is LAW and government regulation, decision-making results, and other supporting data. Christine Daymon and Immy Holloway (2008:321), explaining that observation is about logging and systematic recording of an event, artifacts, and informant behaviors occurring in certain situations, not like the last They remember, retold, and generalized by the Parrtisipan itself. The observation methods are rarely used alone, but are often associated with interviews. Creswell describes that: "Data collection as a series of interrelated activities are aimed at collecting information to answer emerging research questions (Cresswell, 2014:206)." Furthermore, Gay mentions that data collection is a business limiting the research to collect information through good observation and unstructured interviews, documentation, visual materials, as well as the business of designing protocols to record and record information (Gay\&Hal, 2003:413-423).

\subsection{Data Analysis and Presentation Techniques}

Data that has been collected, processed and analyzed in a descriptive. The scope of analysis can be explained as follows: (1) Implementation policy of the Regent's authority to Camat in the affairs of regional autonomy in Nias Regency; (2) Factors that inhibit the implementation of policy of the Regent's authority to Camat in the affairs of regional autonomy in Nias Regency; (3) Recommendation model implementation of policy of the authority of the regent to Camat in the affairs of regional autonomy in Nias Regency.

Further analysis is conducted through the stages according to Miles and Huberman (1994): (1) data reduction, (2) data presentation and (3) draw conclusions or verification. These three ways are interconnected and are tools of analysis activities that allow data to be meaningful. Data reduction is a process of electoral, centring attention, simplification, abstracting and transformation of abusive data arising from records made in the field. Thus the data reduction lasts continuously as long as the research is implemented. At the beginning and during data collection, researchers should already create summaries, develop coding categories, create notes, and memos and sort the data. Therefore, it can be explained that data reduction is a form of analysis that is to sharpen, classify, direct, remove unnecessary, and organize data in such a way that final conclusions can be withdrawn and recommended.

Data presentation is the preparation of complex information into a systematic form, so it becomes more selective and simple and understandable meaning. The presentation of the data is intended to provide the possibility of withdrawal of conclusions and recommendations for the problems investigated. In the context of this research presentation of data is done by structuring systematically so it is expected that no links are disconnected. It is intended to avoid minimal confusion. 
Withdrawal of conclusions or verification is an important third activity of data analysis. Since the beginning of data collection, researchers seek the meaning of data obtained. For that purpose researchers seek explanation patterns, possible configurations, causation and so on. From the analyzed data then researchers took a conclusion. Withdrawal is only part of the configuration intact. The conclusion that emerges from the data obtained in the field is analyzed and tested in truth, its efficacy during the study in order to obtain an objective conclusion and can be guaranteed validity.

\section{Result and Discussion}

\section{Implementation of the Regent Authority policy to Camat in Nias Regency.}

Implementation of policy of the delegation of authority of the regent to the government in Nias Regency is implemented by guiding the local head regulation in this case is in the form of Nias Regent rules with application that still depend on the technical service That handles the task field authorized to Camat. In another form of understanding that illustrates the implementation of the Regent's authority to the Camat is still considered not yet fully contains the intention that Camat carry out the regional autonomy in the district. It is considered that the delegation of the authority of the regional autonomy to Camat submitted by the Nias Regent has not yet arrived at the actual authority necessary to be submitted directly to the Camat to determine community service decisions in District. This is motivated by the regulation that has been made is as far as regulation of Nias Regent Number 29 year 2005 about the delegation of micro and Small Business License authority to the government in the Nias regency. In the regulation, the government is given a task in the aspect of granting micro and Small Business license (IUMK) for micro and small enterprises (PUMK). In general, in carrying out the authority that has been bestowed on Camat in Nias Regency in conducting regional autonomy affairs is still limited to the management of data collection and reporting of community services when it comes to proposal Community service is still up to the extent of the recommendation or the provision of public information in the district on the proposal of society itself.

\section{Factors that inhibit the authority of the regent to Camat in Nias Regency.}

\section{Environmental Condition Factor}

Factors of environmental conditions have an important role in implementing the policy of Regent Authority to Camat. Environmental conditions referred to here are the conditions of the working environment in the district office. Because if the condition of existing environment has been established well then the implementation of the construction of the head to the staff/employees can be called successfully. Based on the results of the research conducted in 10 districts of Nias Regency can be seen that has been realized environmental conditions that support the development of Camat to staff/employees. This is seen from the mutual and mutual respect between leaders and staff. It is also influenced by the socio-cultural environment in Nias Regency which is a mutual respect regardless of status, such as the age difference between the Camat and staff/employees. What although Camat in Nias Regency has a younger age than the Secretary of the Camat and other employees but 
this is not the reason for them to not respect each other. So the implementation of the construction conducted by the Camat has been running well because it has been supported by good environmental conditions.

But the environmental condition between the staff is not well-established and there is still a misunderstanding that causes disputes between employees one and other employees. This certainly affects the process of coaching that will be performed by the leadership. Because in the process of coaching requires cooperation between staff in order to implement the construction done by the Camat. Thus to overcome these constraints, it should be more concerned with the relationship between staff by making activities/programs in order to strengthen the relationship between staff.

\section{Relationship Factor between Organizations}

The relationship factor between organizations affects the achievement of policy objectives. In LAW No. 23 Year 2014 Article 209 is said that the subdistrict is one of the regional devices of the district. Every program implemented by the Sub-district must be Dipertanggung-jawabkan to the local government. In implementing the implementation of the policy of the delegation of authority to be implemented there must be supervision of the giver is the Regent or district government. Because supervision is very important to know whether the delegation of authority given has already walked as assigned or not.

Thus, in order to make the implementation of the policy well done, the local government needs to improve oversight in 10 sub-districts in Nias. When a policy has been made, the policy should be implemented and the outcome as can be in accordance with what the policymaker expects. A policy has a clear purpose as a policy orientation form. The objectives of policy implementation are formulated into specific action programs and projects designed and financed. Program implemented according to the plan. Implementation of policies or programs - in an outline - is influenced by the content policy and implementation context. The overall policy implementation is evaluated by measuring external programs based on policy objectives. The external program is seen through its impact on the intended goals of both individuals and groups and communities. The external policy implementation is the change and acceptance of changes by target groups.

Therefore, the author argues that in large line the delegation of authority will not be able to run without the support of both financial resources, facilities and HUMAN resources. Delegation of authority from the regent to Camat in Nias Regency to be able to run well, then the effort to overcome the obstacles how to make the Regent to give the authority to Camat not half-hearted and The political will to give the delegation of authority to Camat in Nias Regency. In addition, the need to arrange and inventory of authorities that may be able to be bestowed in accordance with his needs through coordination with the Department and other regional technical institutions to obtain the authority that may be bestowed upon Sub-district government, and with an ununiform pattern tailored to the needs of its territory. The important thing is the human resources (officers) who will perform the delegation of authority so that the evaluation is thoroughly related to human resources and to develop the approximate needs of personnel by looking at the number and quality. Estimate the needs of 
budget for the district in the implementation of the delegation of authority from the regent to Camat carefully and the minimization of unnecessary budget needs by memper-point year-running APBD and subsequent years.

Law Number 23 of 2014 and government Regulation No. 19 year 2008 about the subdistrict reaffirm the authority of the Camat. The attributes of the Atributive authority remain in place as a delegated authority delegate of the Regent/mayor. In conjunction, Camat was emphasised to receive authority from the Regent/mayor. The main principle in authority delegation is delegated authority, which is attributable authority, while delegative authority cannot be delegated to other parties, as it will complicate the financing and Held accountable.

It can be argued that the principle in giving authority delegation should give attention to the contents of the policy and the context of its implementation. The content policy concerns the influence of existing interests, benefits gained, clarity of purpose, implementation programs and the support of both financial and personnel resources, while in the context of the implementation of policies concerning the form of and indicators of authority, interests and strategies, the character of the regime of leadership and organization and responsibility.

In order to realize success in the implementation of authority delegation required the harmony between the principles underlying with the practice of organizing autonomy supported by the capabilities of human resources, finance, equipment and Organization and Management. The administrative goal of decentralization is the development of local government administration system that is able to provide excellent service to the community and prioritize effective, efficient, equity and economic value. While the socio-economic objectives of decentralization are improving the welfare of the external and inward communities.

Today's community conditions are given greater opportunities to develop their aspirations and initiatives in the framework of regional development. The role of each of these parties should ultimately be transformed into a powerful force to manage the area, especially in anticipation of strategic issues relating to the development of areas both internal and external.

Delegation of authority from the regent to Camat is necessary to improve the quality of service to the community. In addition, the implementation of general governance tasks can also be implemented effectively and efficiently because Camat more familiar with the region than the regent. However, in the implementation of some obstacles in the delegation of authority, obstacles that may arise are not yet a good coordination between the SKPD because of the anxiety will take some authority that It has. Delegation of authority will not be able to walk without the support of good resources in the form of financial, means and human resources. There is a conflict of interest between the agency and the local technical institution in Nias Regency, this may be the case for the more important is to prioritize the interests of society and the best service.

The quality of human resources is a fundamental obstacle to the implementation of the delegation of authority from the regent to Camat, including in 10 districts of Nias Regency. Supporting fund that does not support for the delegation of authority from the regent to 
Camat is an obstacle to the implementation of the delegation of authority from the regent to Camat in Nias Regency, because the delegation of authority must be followed by For the operations of a delegated activity. Support facilities and infrastructures in 10 (ten) Nias District does not support the delegation of authority from the regent to the Camat, so it is necessary to add facilities and infrastructure.

Factors that become barriers to the implementation of the policy of the delegation of the authority of the regent to Camat in providing services to the community, namely as follows:

1. Service conducted not integrated, in the sense of service process in 10 Nias Regency has not been through one door and must go through the procedures in each section in accordance with the task, so that the path of bureaucracy is longer .

2. There is still overlaps authority with the technical service or other agencies, so the implementation of service becomes not optimal.

3. The pattern of Uniform Authority delegation to all sub-districts make the pattern of service become equal and there are no specifications tailored to the needs of local people.

4. Lack of human resources (HR). District officials are still impressed to do the work that is routine and impressed, it is in accordance with the statement of Camat in Nias regency that says that employees ' understanding of the principal task is still limited considering that from the resource Humans are different background education and more high school educated. Where they don't want to learn again finally miss the planned information.

5. Conditions of the working area are different from other sub-districts seen from the geographical state and state of the population. The geographical state is largely a land in the form of rice fields or agriculture, a settlement with a density that is still not relatively dense. And the pattern of task and function of each sub-district is still the same without a pattern that is visually safe.

6. Facilities and infrastructures that are still numbered incomplete, actually in the district need to be applied and use a computerized system that is integrated directly into the district so as to directly create public documents such as KTP, KK, and To support the most effective and efficient azas services to the community. Such things can move the spirit of the community to the orderly administration and ease in terms of distance making the community do not need to come far to the district city.

Delegation of authority from the regent to Camat in Nias Regency to be able to run well, then the effort made to overcome the obstacles how to make the Regent to give his authority to Camat not half-hearted and The political will to give the delegation of authority to Camat in Nias Regency.

In addition, the need to arrange and inventory of authorities that may be able to be bestowed in accordance with his needs through coordination with the Department and other regional technical institutions to obtain the authority that may be bestowed upon Sub-district 
government, and with an ununiform pattern tailored to the needs of its territory. The important thing is the human resources (officers) who will perform the delegation of authority so that the evaluation is thoroughly related to human resources and to develop the approximate needs of personnel by looking at the amount and quality. Estimate the need for a district budget in the implementation of the delegation of authority from the regent to Camat carefully and the minimization of the need for unnecessary budgets by memper-point year-running and years in the future .

\section{Model Implementation Policy of the authority of the regent to Camat in Nias Regency}

The implementation of a policy is essentially a change or transformation that is multi-organizational, where the changes applied through this policy implementation strategy associate different layers of society. Therefore, success is highly determined by the right policy strategy that can accommodate a variety of different views and interests in society. Policy implementation is a strategic stage in the public policy process. A policy must be implemented in order to have the desired impact or objectives. The policy implementation phase will not start before the goal and goals are set first by the formulation of the policy. Thus, the policy implementation stage occurs only after the law is established and funds are provided to finance the implementation.

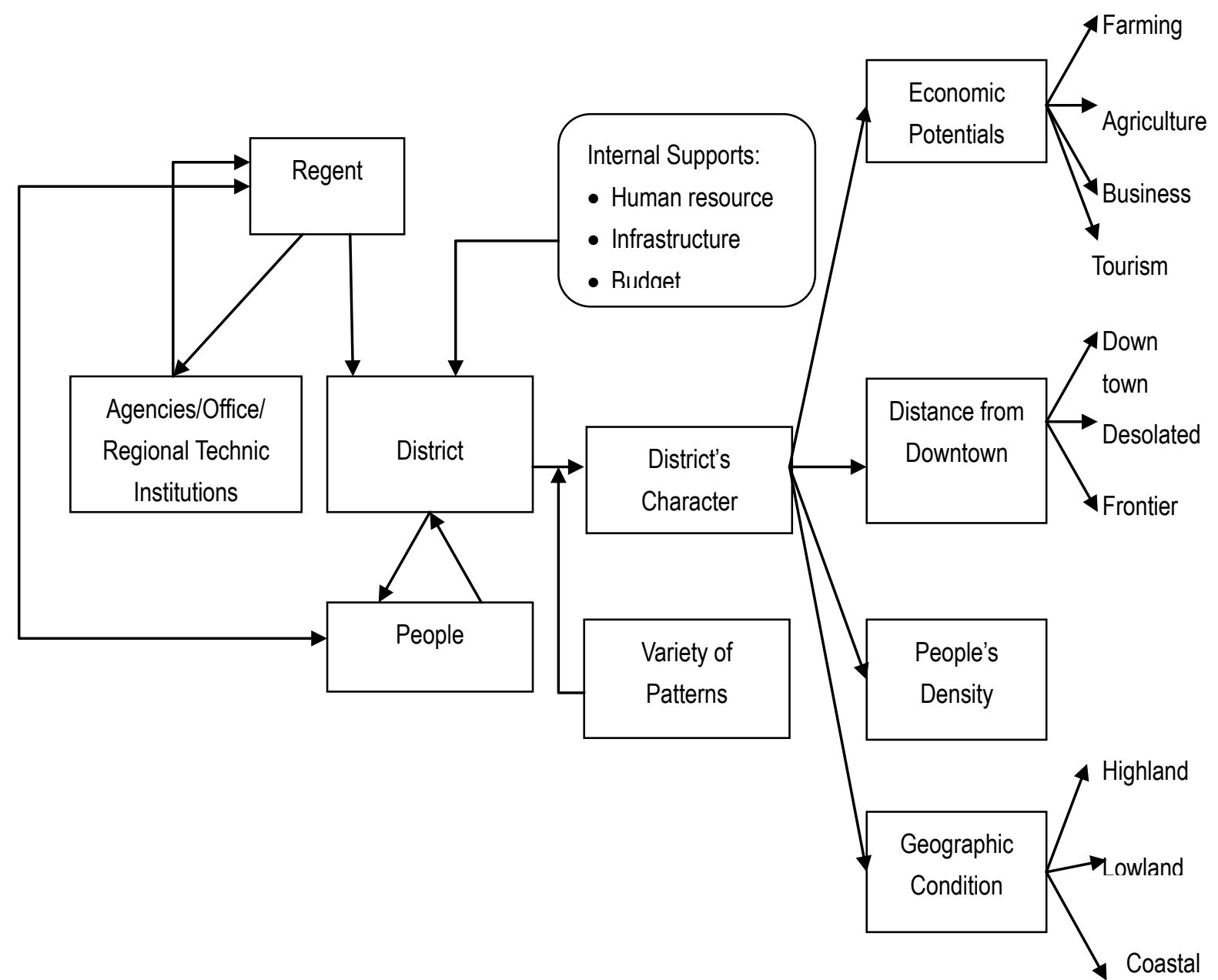

Figure 1. Model implementation of discretion of Regent Authority To Camat in Nias Regency 


\section{Macrothink}

The model description above is a researcher's view in noticing the need for authority delegation to Camat covers some of the groovle models and institutional structuring according to Sadu. The above describes (image descriptions) as follows:

1. Regent has a willingness and commitment to delegate authority to the head in the affairs of regional autonomy.

2. Regent provides duties and functions to the Department and technical institutions.

3. The regent draws back some of the duties and functions that have been given to the technical institutions and the Dinas to be bestowed on the Camat in order to accelerate public service and to draw closer to the community and to the governance of the Government to the Camat. This has been preceded by the Legawa attitude of the technical institution and the service to give the task and its function to be implemented by the Camat.

4. District after being given the delegation of authority from the Regent carries out its duties and functions for the public service.

5. People provide feedback to the community in order to create a good public service.

6. The community gives feedback to the regent as a party that gives the authority to the social authorities on how the conditions of the pubic service conducted by the community to the public.

As well as the Regent periodically conducts evaluation, monitoring and supervision of public service conditions that occurred as a result of the delegation has given authority to the Camat.

7. District and regional technical institutions as well as good service units that are located in the Sub-district continuously coordinate in order to create a good public service.

8. Camat periodically provide a report to the regent as an authority on the condition and results of public services conducted in relation to the authority of the regent to Camat.

9. District Given the delegation of authority from the regent is not the same to every subdistrict but with a variety of patterns by looking at the characteristics of the subdistrict.

10. The pattern of diversity is given to the Camat as a form of the delegation of some authority of the regent to Camat due to the characteristics of different districts of each other.

11. The Government in the governance requires support: human resources, infrastructure, and budget so as to perform the delegation of some authority of the regent to Camat.

Therefore, the author argues that in large line the delegation of authority will not be able to 
run without the support of both financial resources, facilities and HUMAN resources. Delegation of authority from the regent to Camat in Nias Regency to be able to run well, then the effort made to overcome the obstacles how to make the Regent to give his authority to Camat not half-hearted and The political will to give the delegation of authority to Camat in Nias Regency. In addition, the need to arrange and inventory of authorities that may be able to be bestowed in accordance with his needs through coordination with the Department and other regional technical institutions to obtain the authority that may be bestowed upon Sub-district government, and with an ununiform pattern tailored to the needs of its territory. The important thing is the human resources (officers) who will perform the delegation of authority so that the evaluation is thoroughly related to human resources and to develop the approximate needs of personnel by looking at the number and quality. Estimating the budget needs for the subdistrict in the implementation of the delegation of authority from the regent to Camat carefully and the minimization of unnecessary budget needs by paying attention to the year and subsequent APBD years.

In addition to the above, in carrying out the authority relating to coordinating Community empowerment, Active Society provides regional coaching and various appeals related to community empowerment. Camat which is still perceived by some communities as the head of the region even part of the village head and Lurah is considered a figure that is able to give uniting ideas that are able to provide solutions to the development of . The perception also strengthened its competence in the thorough coordinating of both the village heads and the people directly.

\section{Closing}

The implementation of power delegation from the mayor to the district coordinator of Nias Regency was conducted in accordance to the regional law, which comes in the form of Nias' Mayor's Decree with an application that depends on the Technical Department who handles the field tasked by the district coordinator. In other words, the implementation of the mayor's authority to the district coordinator is still considered to be an incomplete delegation of power for the district coordinator to conduct an autonomous management of the district. This means that the delegation of power for regional autonomy to the district coordinator from the Mayor of Nias has not yet reached to the authority required by the district coordinator to determine the public services in the district. This is due to the regulation being made solely based on the Mayor's Decree Article Number 292005 regarding the Power Delegation of Micro and Small Business License Allotment to District Coordinator in the Circle of Nias Regional Government. In the decree, the district coordinator is given the task of license allotment for micro and small businesses. Generally, in conducting the authority delegated to the Distict Coordinator of Nias Regency regarding regional autonomy is still limited to the management of data and public service reports, which, if includes a proposal for public services, is still limited to giving recommendations and informations from the community in the district based on said person's proposal.

Several factors which hampers the delegation of power from the mayor to the district coordinator of Nias Regency generally begins with the availability of the district officials' 
human resources who are tasked with conducting the principal tasks in accordance with the task field delegated to the district coordinator being very limited qualitatively and quantitatively. Generally, the amount of district officials' human resources in Nias Regency are mostly still deficient, and this is a common obstruction found in districts considered to be rural areas and are recently-flourished. The quality of officials are still distributed unevenly for each district which still requires the resources that can be used to process technical issues given to the district coordinator. Another factor that contributes to the hampering of the delegation of power from the Mayor of Nias to the district coordinator is the availability of District Budget which could shorten the services to the district community, especially in providing service facilities and information delivery which could give a shortened space for the community to be served. Another factor that hampers the delegation of power from the mayor to the district coordinator is the lack of willingness from the technical department to delegate tasks to the district coordinator, who, in this case, appears to be a long and complicated bureaucracy, and truly affects the delay of regional regulation products in the form of regional regulations which becomes the standard of the district coordinator to fully serve the community as a form of power delegation from the mayor to the district coordinator in Nias Regency.

The model of implementation of the delegation of power from the Mayor of Nias to the district coordinator in regional autonomy of Nias Regency is a form of an interactive model which produces an interactive plot that begins with a commitment of power delegation to the district coordinator in order to conduct regional autonomy issues. This commitment refers to the commitment to accelerate public services, juxtapose officials to the community, and regenerate the government to the district coordinator. This begins with the attitude of the mayor to delegate power to the district coordinator, and then with the willingness of technical institutions and departments to delegate their task and function to be conducted by the district coordinator. Aside from that, it is also expected that the community will provide feedback to the mayor as the party who delegates power to the district coordinator regarding the public services condition conducted by the district coordinator to the community. As feedback from the power delegated to the district coordinator is a track valued by the community itself, who, in its evaluation, is conducted directly by the regional coordinator on a periodical basis with a delegated service quality examination, and a technical management coordinated with the regional technical institution. This delegation policy model is expected to become an effective way to evaluate an effective authority from the community as the starting principle of core service requirements.

There requires an evaluation towards the mayor's decree regarding the delegation to the previous and next district coordinator, and then the mayor revises it by firstly organizing and stocking the authority that may be delegated in accordance with the requirements through coordination with other regional department and institution in order to be able to gain the authority that may be delegated to District Officials, and with a pattern accustomed to the region's requirements. The range of understanding can be further socialized regarding the authority delegated by the mayor to the district coordinator. The socialization aims to grow the understanding of the district coordinator and the district's organizational units as the 
receiver of the authority, so that the authority may be conducted precisely and consistently, and the coordination between district coordinators as the receiver of the authority with related technical institutions in the regency, such as department/agency/office with relation to the conduct of said authority. This is a form of a product of law that manages and governs districts in conducting governmentary tasks which comes from the regency. In wider terms, it does not intend on abusing the power delegated to the district coordinator, but to help the mayor and regional government so that their governmentary tasks do not overload in the regency government office.

Regional governments are suggested to regather the data of the kinds of services that the district community of the Nias Regency requires the most by considering the human resource capabilities of the district officials with various effective public services in accordance with the demography and geography of the region, and adjusts the publice services facility requirement as a form of regional autonomy that expects the district coordinator to be able to conduct the tasks more effectively, efficiently, and equally with decisive legality and autonomous service.

The interactive application of this research study is suggested to begin with the representation of elements that defines the aim of the policy, action program, and certain projects, which are designed in accordance with the aim of the delegation of power from the mayor to the district coordinator with the quality and quantity of the human resources of administrating district officials, which includes the commitment of each district coordinator to conduct autonomous affairs, which is delegated by the mayor of Nias with the public service result consequence that can be evaluated by the community, and is supported with the legality, which is renewed through regional product of law and the willingness of regional technical institutions to delegate technical managements to the district coordinator.

\section{References}

Creswell, J. (2005). Research Design: Pendekatan Kualitatif, Kuantitatif, dan Mixed. Yogyakarta: Pustaka Pelajar.

Creswell, J. (2014). Penelitian Kualitatif dan Desain Riset, Edisi Indonesia, (translated from Qualitative Inquiry and Research Design), Cetakan I. Yogyakarta: Pustaka Pelajar.

Daymon, C., \& dan, I. H. (2008). Metode-metode Riset Kualitatif: dalam Public Relations dan Marketing Communications. Yogyakarta: Penerbit Bentang.

Gay, L. R., \& Airasian, H. A. L. (2003). Educational Research: Comhaletencies for Analysis \& Application $\left(7^{\text {th }}\right.$ ed) New Jersey : Merril Prentice Hall.

Grindle, M. S. (ed). (1980). Politics and A Policy Implementation in the Third World. New Jersey: Princetown University Press. https://doi.org/10.1515/9781400886081

Hamidi. (2005). Metode Penelitian Kualitatif: Aplikasi Praktis Pembuatan Proposal Dan Laporan Penelitian. Malang: UMM PRESS

Hoogerwerf. (1983). Ilmu Pemerintahan. Terjemahan R.L.L. Tobing. Jakarta: Erlangga. 


\section{Macrothink}

Journal of Public Administration and Governance ISSN 2161-7104 2019, Vol. 9, No. 3

Lincoln, Y. S., \& Egon, G. G. (1985). Naturalistic Inquiry. California: Sage.

Marpaung, M. (2014). Pengaruh Kepemimpinan Dan Team Work Terhadap Kinerja Karyawan Di Koperasi Sekjen Kemdikbud Jakarta. Jurnal Ilmiah WIDYA, 2(1). https://doi.org/10.30588/jmp.v2i2.275

Miles, M. B., \& Huberman, A. M. (1994). Qualitative Data Analysis, 2nd ed. USA: Sage Publication.

Muallidin, I. (2013). Kepemimpinan Sektor Publik dalam Perspektif New Public Leadership. Program Doktor Jurusan Ilmu Administrasi Publik Fakultas Ilmu Administrasi Universitas Brawijaya.

Ndraha, T. (2000). Ilmu Pemerintahan Jilid I-IV. Jakarta: Institut Ilmu Pemerintahan.

Rahmawan (2016). Peran Kepala Distrik Dalam Penyelenggaraan Pemerintahan Di Distrik Nabire Kabupaten Nabire, 1(7). Jakarta. 


\section{Macrothink}

\section{Products of Law}

National Act Number 5 in 1974

National Act Number 23 in 2014

National Act Number 6 in 2014

National Act Number 6 in 2016

Government Rules No. 19 in 2008

Government Rules No. 43 in 2014

Government Rules No. 18 in 2016

Regent Rules No. 8 in 2014

LAKIP BKD Kabupaten Nias 2016

LKPJ AMJ Bupati Nias periode 2011-2016

LKPJ Pemkab Nias pada Tahun 2010-2012

\section{Abbreviations \\ Camat : Head of Sub-district \\ Kecamatan : Sub-district}

\section{Copyright Disclaimer}

Copyright for this article is retained by the author(s), with first publication rights granted to the journal.

This is an open-access article distributed under the terms and conditions of the Creative Commons Attribution license (http://creativecommons.org/licenses/by/4.0/). 